\title{
Jolanta Wojciechowska
}

SPRAWOZDANIE Z SEMINARIUM pt. „RZYSZLOŚĆ DLA UJŚCIA ODRY. ZIELONY OKRĄGEY STÓE”, WOLGAST (NIEMCY), 17 WRZEŚNIA $1994 \mathrm{r}$.

LE COMPTE-RENDU DU SÉMINAIRE INTITULÉ: „FUTUR POUR L'ESTUAIRE DE L'ODER. LA TABLE RONDE VERTE", WOLGAST (ALLEMAGNE), 17 SEPTEMBRE 1994

A REPORT FROM THE SEMINAR, „TURE FOR THE ODRA ESTUARY. THE GREEN ROUND TABLE", WOLGAST, GERMANY, 17th SEPTEMBER 1994

W dniu 17 września 1994 r. powiatowe miasto Wolgast w Meklemburgii (Niemcy) było miejscem jednodniowego seminarium przy „Zielonym Okragłym Stole" skupiającym polityków, naukowców, przedstawicieli życia gospodarczego oraz różnych zrzeszeń i organizacji, zarówno strony niemieckiej jak i polskiej. Lącznie w seminarium uczestniczyło ponad 40 osób. Spotkanie to, którego hasłem przewodnim było: „Przyszłość dla Ujścia Odry” zorganizowane zostało przez międzynarodową organizację Naturfreunde Internationale, skrót niemiecki NFI (Międzynarodowa Organizacja Przyjaciół Przyrody) oraz die Stiftung Oder-mündung (Fundacja Ujścia Odry).

Organizacja NFI, której powstanie sięga połowy lat dziewięćdziesiątych XIX w., ma na celu $\mathrm{m}$. in. czynne propagowanie ochrony środowiska przyrodniczego poprzez włączanie się w taki rozwój przemysłu i turystyki, które nie niszczy sfery kulturowej, socjalnej i środowiska naturalnego. Siedzibą tej organizacji jest Wiedeń. W $1987 \mathrm{r}$. NFI podjęła decyzję przyznawania co roku jednemu regionowi tytułu „Krajobraz roku”. Celem takiej akcji jest zwrócenie uwagi społeczeństw na regiony, głównie przygraniczne, o dużym znaczeniu ekologicznym, z jednoczesnym ukierunkowaniem na konieczność ich ochrony przed pojawiającymi się zagrożeniami. Uznanie obszaru „Krajobrazem roku” jest więc pierwszym krokiem w kierunku poznania środowiska geograficznego regionu, zrozumienia potrzeb życiowych mieszkających tam ludzi, dostrzeżenia jego szans i zagrożeń ekologicznych. Podejmowane działania mają prowadzić do zachowania przestrzeni życiowej na przyszłość, a więc tego co dziś określa się mianem sustainable development (zrównoważony rozwój). Osiągnięcia tego celu, pogodzenie rozwoju gospodarczego z ochroną środowiska, ekonomii z ekologia, wy- 
maga żmudnej pracy, nad którą pieczę przejęła organizacja NFI. Organizacja ta posiada status konsultanta przy Radzie Europejskiej i przy UNESCO.

Po raz pierwszy tytuł „Krajobraz roku” otrzymało w 1989 r. Jezioro Bodeńskie (Austria, RFN, Szwajcaria), w 1990 r. Jezioro Nezyderskie (Austria, Węgry), a w latach 1991-1992 góry Eifel-Ardeny (Luksemburg, Belgia, RFN). „Krajobrazem roku” 1993-1994 ogłoszono region „Ujście Odry” położony w strefie przygranicznej Polski i Niemiec. Biuro tego regionu znajduje się w Greifswaldzie, a jego przyszłość była w ciągu ostatnich lat tematem wielu spotkań i seminariów. Setki ludzi zaangażowało się w dyskusję: mieszkańcy, związki, firmy, organizacje lokalne, politycy i naukowcy (głównie z ośrodków uniwersyteckich w Greifswaldzie, Rostocku i Szczecinie).

Celem obecnego seminarium było podsumowanie wyników dotychczasowej pracy oraz przedstawienie katalogu postulatów, których spełnienie warunkuje sustainable development regionu. Seminarium to było ostatnim w cyklu dwuletnich spotkań podejmowanych przez NFI. Kontynuację dalszych idei jak i działań realizacyjnych podjęła się powołana w tym celu Fundacja „Ujście Odry Związek Regionalny Trwałego Rozwoju” z siedzibą w Ducherow koło Anklam (Niemcy).

Program seminarium składał się z dwóch części: referatowej i dyskusyjnej. W ramach tej pierwszej wygłoszone zostały następujące referaty:

- Samodzielny rozwój regionalny przez inicjatywy oddolne, dr Uwe Kerstan, przewodniczący Fundacji „Ujście Odry - Związek Regionalny Trwałego Rozwoju";

- Rezerwat Biosfery Ujścia Odry - niezagrażajaca środowisku gospodarka dla przyszłości, Przemysław Zyska, przewodniczacy „Rezerwatu Biosfery Regionu Ujścia Odry", pracownik Urzędu Wojewódzkiego w Szczecinie;

- Idealy i cele ochrony środowiska w rozwoju przestrzennym regionu Ujścia Odry, Matthias Holst, Biuro Prognoz w Berlinie.

W referatach autorzy starali się wykazać jak wiele szans społeczno-gospodarczych kryje w sobie obszar Ujścia Odry. Najistotniejsze wg nich to: zachowana w prawie naturalnym stanie przyroda oraz postępujący rozwój turystyki i ekologicznego rolnictwa. Podawane były również przykłady wielu zagrożeń, np. stan czystości wód na tym terenie, a także sytuacja komunikacyjna (tj. zbyt mała liczba przejść granicznych, brak ciągłości linii kolejowej po obu stronach granicy itp.). We wspólnym, transgranicznym rozwiązywaniu problemów autorzy widzą nadzieję na znaczącą poprawę.

Część dyskusyjna seminarium koncentrowała się wokół następujących tematów:

- rozwój niezagrażającej środowisku gospodarki zwłaszcza w dziedzinach rzemiosła, handlu, przemysłu i komunikacji,

- ekologiczne rolnictwo - szansą dla ludzi oraz cegiełką dla samodzielnego zabezpieczenia bytu tego regionu, 
- koncepcja i model rozwoju łagodnej turystyki jako jeden z kroków ku „zrównoważonemu rozwojowi” regionu.

$\mathrm{W}$ odniesieniu do ostatniego $\mathrm{z}$ wymienionych tematów autorka niniejszego sprawozdania przedstawiła koncepcję i metody badań w zakresie rozwoju turystyki na terenach wiejskich Polski Środkowej prowadzonych przez Katedrę Geografii Miast i Turyzmu Uniwersytetu Lódzkiego. Zaprezentowała również wstępne wyniki badań prowadzonych w latach 1990-1994 nad świadomością turystyczną mieszkańców i urzędników gmin, co spotkało się z żywym zainteresowaniem zgromadzonych i znalazło swój oddźwięk w dalszej części dyskusji.

W tej części seminarium zaakceptowany został również Katalog postulatów dla „Krajobrazu roku” 1993-1994, jako baza do podejmowania dalszych decyzji politycznych i realizowania kolejnych celów w tym regionie. Katalog ten, wydany w formie broszury, został dostarczony wszystkim zebranym. Zawiera on postulaty w zakresie turystyki, komunikacji, ochrony przyrody, rolnictwa i leśnictwa, ochrony wód oraz działalności wojska. Organizatorzy zapewnili również bogaty materiał informacyjny zarówno z dokonań akcji „Krajobraz roku”, jak i organizacji NFI, oraz pokrewnej ÖTE (Ökologischer Tourismus in Europa) ${ }^{1}$, której przedstawiciele także uczestniczyli w niniejszym seminarium. Największym powodzeniem cieszyła się mapa regionu Zalewu Szczecińskiego, przedstawiająca i opisująca międzynarodową ścieżkę rowerową wokół Zalewu. Epilogiem seminarium była uroczysta prezentacja przez sekretarza generalnego NFI (Manfred Pils) interesujących przeźroczy $z$ terenu alpejskiego $(\mathrm{m}$. in. Dolina Lesenthal na pograniczu Austrii ze Słowenia) jako zapowiedź przyszłego obszaru do tytułu „Krajobrazu roku”.

${ }^{1}$ Patrz - Sprawozdanie z sympozjum nt. "Turystyka ekologiczna w Brandenburgii", "Turyzm" 1993 , t. 3, z. 1 . 